\title{
繊維染色加工場におけるオープン工場方式による生産システムの開発
}

\author{
Development of a Production System by an Open Factory Method in a Fiber Dyeing Company
}

岡田正幸

\section{1. 開発経緯}

近年、海外生産の繊維製品が日本国内に多く輸入され、 毎年売上高、受注量も減少してきています。残念ながら、 この傾向は、今後益々、加速されるとも考えられます。

また、品質、納期に対する顧客からの要求も質の高いも のになってきました。一方、紡績、商社の生地企画提案力 が、繊維業界全体の景気悪化による人員削減、自社染色工 場の閉鎖、それに伴う若年化などによる経駼知識不足に よって、低下したこと、また、紡績 商社の海外生産シフ トによって、国内生産量が少なくなってきております。こ のままでは、企業存続の危機を感じました。その対策の一 つとして、このシステムを開発したものであります。

要約(開発が必要になった背景)

1. 染色加工職人の不足化

2. 染色効率の向上(調色再現性のアップ、仕掛負荷の低 減短納期対応）

3. 夜間無人運転の実現による合理化

4. 社員の意識改革

\section{2. 開発コンセプト システムコンセプト}

1. IT 時代に対応可能なネットワーク型システム

2. 自動染色機との連動

3. 各種社内情報の共有化

4. インターネットを利用した得意先との情報共有化と情 報公開(自社工場のように安心して加工を委託できる染 色工場になるように）

\section{3. 技術概要}

投入工程から最終工程まで、繊維染色工場はきわめて多 くの工程を有する生産ラインがあり、全生産工程の進渉を 管理することはきわめて重要である。また未投入加工分に

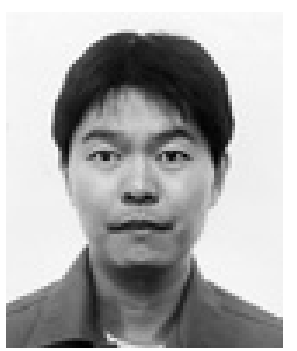

MASAYUKI OKADA

飯田繊工株式会社 次長 工学士

干533-0022 大阪市東淀川区菅原 2 丁目 2 番 104 号

Tel : 06-6328-3361 Fax : 06-6328-7983 〈専門〉応用化学

〈趣味〉ハイキング、キャンプ、旅行
ついても進渉予想、納期報告納期管理も重要である。この 場合個々の生産工程の生産負加や工場全体の負加などをリ アルタイムに把握し、その現実の負加進渉に基づいて生産 体制を最適に設定しなおすこことが望まれる。また顧客に対 しても変動あるきわめて多くの工程進渉状況の報告も望ま れる。ただ従来の染色工場管理は、営業システム、生産シ ステム、工場自動化システム、などのコンピューターシス テムが一元化されておらず、工場全体として瞬時に把握す る事に難を要していた。そのために現実の進渉に基づいて リアルタイムに生産体制を最適に設定しな打すことができ ない。またリアルタイムに顧客にも生産状況を報告できな かった。さらには生産実績情報についても、今後の加工に 有効に利用できていなかった。この解決のために新方式を 創出したことにより、見事に解決いたしました。その概要 は以下の通りである。

3.1 コンピューターシステムの一元化。

受注管理システム、生産管理システム(営業 生産 技 術などにおける)、工場自動化、管理システム(染色機の自 動化)、(総務 経理 資材)などに打ける事務管理システ ムをネットワーク結び、情報の交換をスムーズにし、より 正確 容易に個々の管理システムの精度を向上させた。

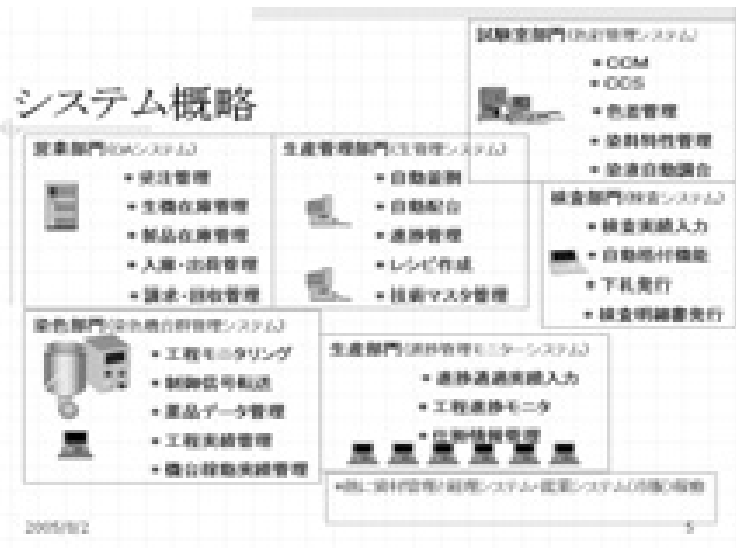

個々のシステムの概要と運用

\subsection{1 生機入荷処理}

生機がニッターから入荷されると納品書記載の詳細な情 報が入荷端末に入力され、生機在庫票と反番を含むバー コードが出力されて各反物に貼られる。

格納する場所は在庫量と品種、入荷先等から適切な階と 
棚番が自動検索される。

オンラインで入荷案内の交信を行っているユーザーはこ の時点で入荷内容が確認される。

\section{1 .2 受注管理}

加工の依頼があれば直ちに加工内容が受注端末に入力さ れ、加工指罒情報としてデータベースに格納される。レピー 卜受注の場合は過去の受注情報が検索されて、加工内容、 染色処方等が自動設定される。

オンライン交信を行っているユーザーはその情報が自動 的に取り込まれる。

\subsection{3 ロット編成と生産予定}

新規に発生した加工指困情報はリアルタイムに生産情報 が生成される。

納期、加工数量、生機品種、仕上げ規格等から加工工程 を自動展開し、各工程の負荷状態を参照しながら、適切な ロットに編成して染色予定と各工程の生産予定に組み込ま れる。

この時、生機の在庫とレサイプ状況を照合して投入可能 のものは予定が先行される。

\subsection{4 進渉管理}

生産予定に載った受注は各生産部署のコンピューター端 末に進行別に色分けされたモニター画面に掲示される。各 持ち場に加工品が流れてくると、着手のバーコードを読ま せ、作業完了すると完了のバーコードを読ませる。作業内 容が特殊な場合には、加工情報の問い合わせ機能で詳細な 内容が閲覧できる。

もし、作業中に不良反があれば、ただちに再加工指示の バーコードを読ませる。

\section{1 .5 染色機台の群管理}

染色機台は機種、処理能力により数十台単位で群をなし、 各群は群管理システムにより給水/排水、昇温/冷却、染 料・薬品の注入等、全ての動作が集中的に自動制御される。 生産予定に従って生機の準備、シル加工等の前処理が完了 すると、その染色機台特性に合わせて制御信号が組み立て られて送信される。

生機が機台に投入され、染料の準備ができるとスタート する。

\section{1 .6 染料の計量処理}

生産予定のモニター画面をタッチすると、該当のレサイ プから投入数量に見合う計量データーが計量装置に送信さ れ計量される。必要なもののみ計量し、過剩準備による染 料・薬品の傷みをなくする。計量完了したものは、使用量 を資材管理の消費量実績データーに供する。

\subsection{7 仕上げと検反}

全ての工程の最後に仕上げ検査、または巻取り検査を行 う。仕上がった各反物は長さ、重量、巾、十数項目の欠点 検査、縮率検査、用途に応じた堅牢度等が検査される。検 反端末に表示される過去の実績と目標値を参考にして品質 の挌付けをおこない、バーコード付きの製品明細票を貼付 して製品在庫、または出荷現場にまわす。

\section{1 .8 出荷処理}

予め入力格納してある、ユーザーからの出荷指図情報に もとづき、仕上がり状況と検査結果を照合して、合格した もののみが出荷現場に対して出荷指示される。出荷現場で はハンデイバーコードリーダーによって反物のバーコード を読み取り、出荷明細伝票と送り状を印刷して出荷する。 出荷明細情報は毎月の加工傊請求業務のデーターとして経 理システムに送られる。

\subsection{9 技術情報管理}

ロット編成時点で検出される予備試験の警告掲示(新色、 新素材、新品番等)に基づき、現場処理に先だって予備試 験が行われる。新色の場合は CCM、染料自動調合装置に て調色し、機台制御信号の基礎となる染色レサイプが作成 される。

\subsubsection{0 資材管理}

最も重要な資材である染料薬品の適正在庫数量は、生産 予定により予測される。現在在庫量は、計量システムから 送られる使用実績で算出され、適正在庫を切るものは発注 警告が掲示される。

\subsubsection{1 労務管理}

出勤/退勤の時刻、残業時間等は各部門に設置する入力 端末から、社員証のバーコードを読ませることで勤務デー ターが蓄積され、生産実績情報とリンクして採算計算の基 情報となる。このデーターは自動的に給与システムにも送 られる。社員番号は各工程の作業担当者の入力にも使用さ れ、勤務評価の参考資料となる。

\subsubsection{2 社内情報の掲示}

刻々と変化する情報は、常時抽出・集計 ·分析アプリ ケーションによって各部門で必要とされる情報に再編成さ れる。全工程の現在負荷明細、本日出荷可能明細、現在生 産高速報、再加工発生速報、生機未入荷督促等を各部門の 端末に掲示する。特に緊急を要するものは、担当者の携帯 電話に自動メールされる。

\subsubsection{3 情報の社外提供}

顧客が必要とする出荷報告、進渉実績と予定、生機在庫 明細、製品在庫明細等が当社ホームページに自動掲示され る。 
閲覧できるのは顧客自身の情報のみで、内容は copyし て自由に編集・加工が可能。

\section{2 実績蓄積型の生産管理システムの構築}

加工実績情報を解析して、次回の加工 納期設定に役だ てる事ができる。

\subsection{1 生地品種、組織、素材による加工工程の自動設定}

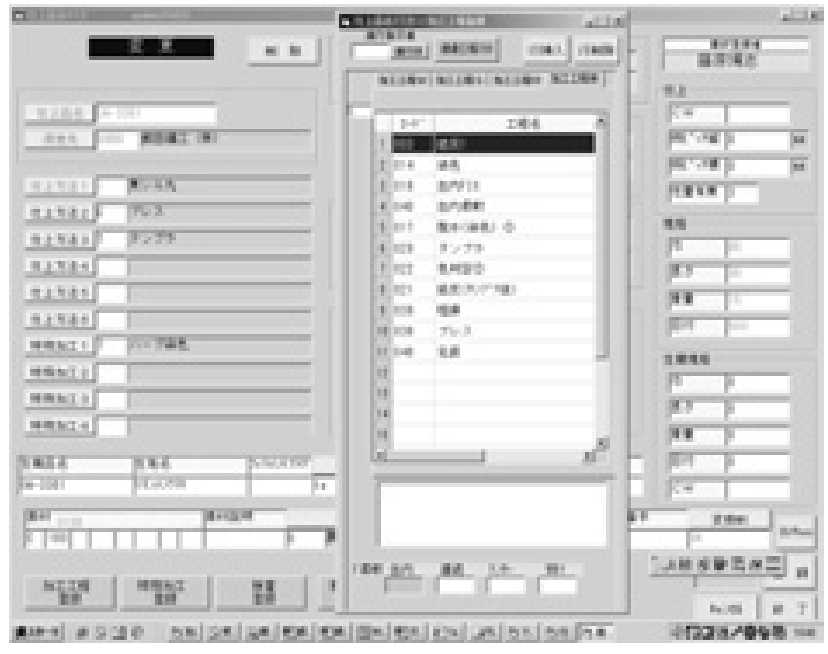

3.2.2 自動納期設定 (工程負荷状況、加工機台などを複合 的に情報を整理して実績値から算出）

\section{事例IV (画面)}

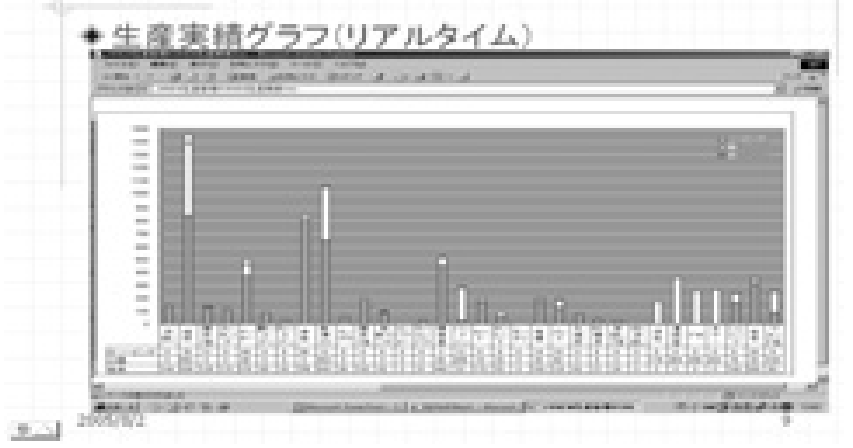

\section{事例 V (画面)}

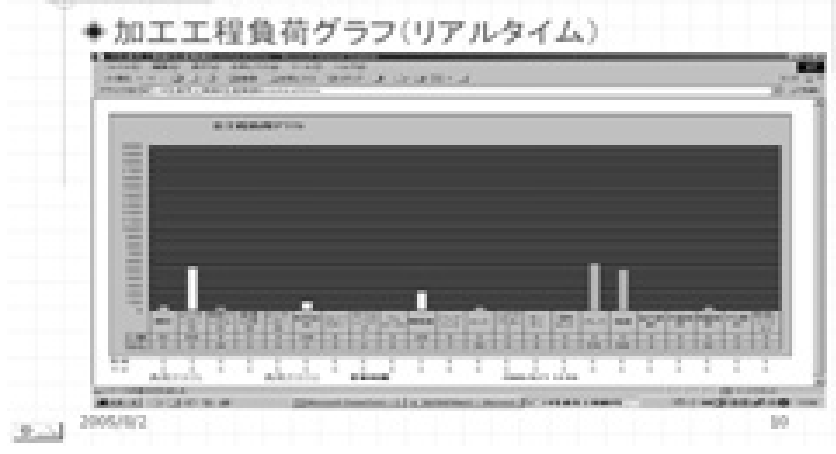

\subsection{3 染色条件の自動設定}

\section{事例 IIII (画面)}

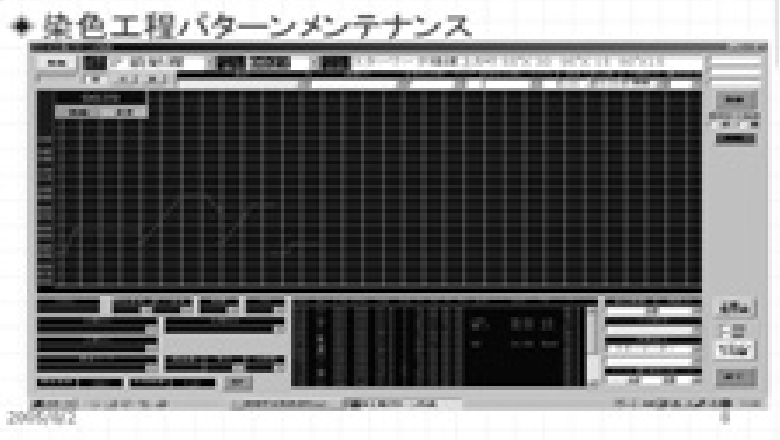

3.3 顧客に対してはインターネット(飯田繊工株式会社の ホームページ)を利用したリアルタイムな加工進渉状 況などの情報の公開。

また社内に対してはイントラネット(各工場内のコン ピューター端末)を利用したリアルタイムな工場全体の負 加状況、個々の工程負加、受注状況、技術情報、生産状況 などを公開。

*社内ホームページ (イントラネット)

事例 I（再面）

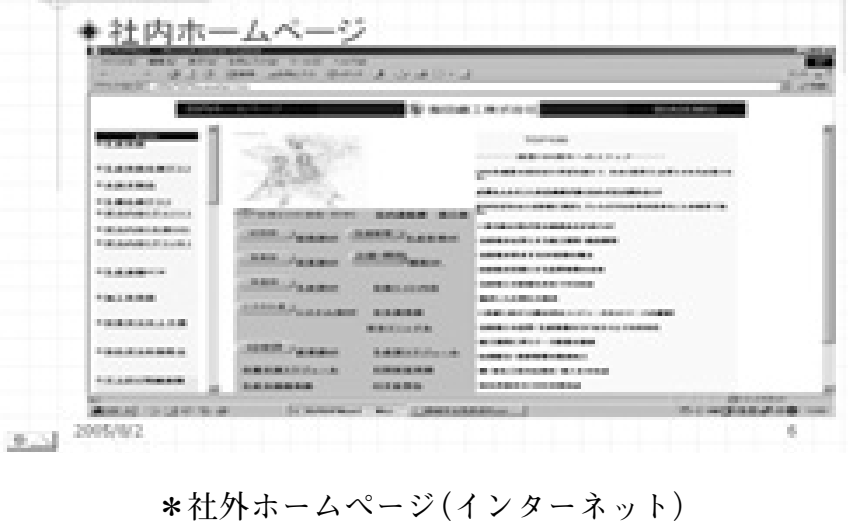

业例VII (画面)

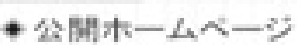

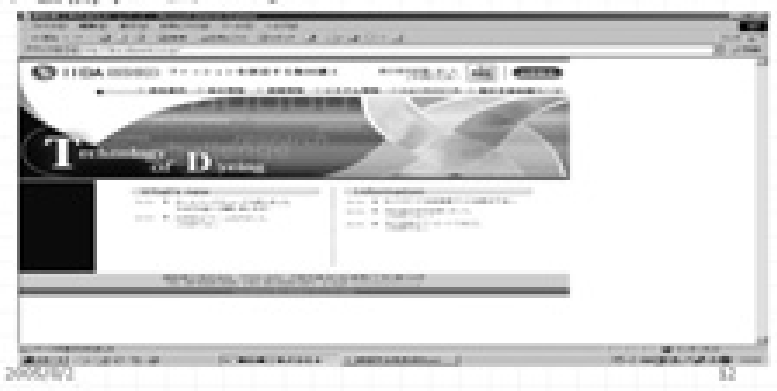

来例VIII（画面）バスワード

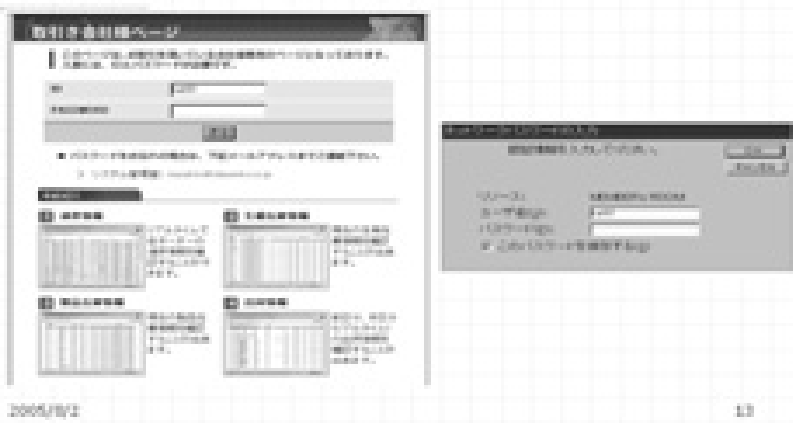




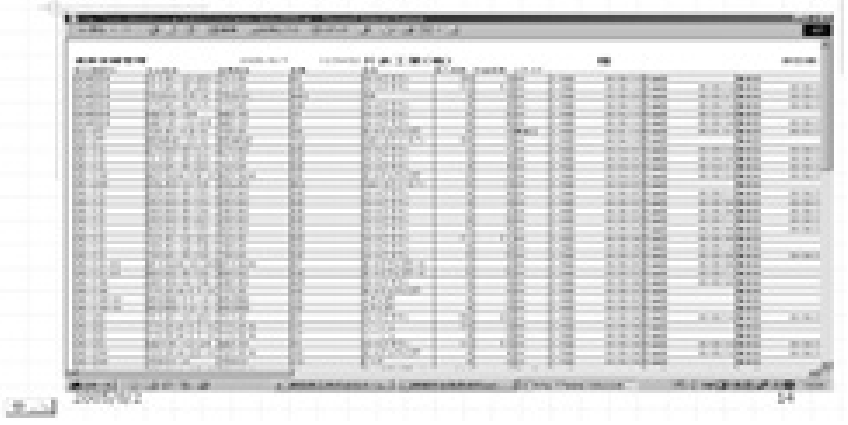

4. 技術の効果

染色整理業は古くから委託加工業という特殊な商売形態 でもあり(顧客より生地を預かり、染色して顧客へ御返し する)。そのために打預かりしている生地の生産状況につ いて顧客がインターネットにアクセス可能なコンピュータ 一があれば、世界中どこでも 24 時間(1 時間毎の自動更新 のため非常に的確な生産状況) 確認可能であり、顧客に対 しては透明感のある、安心できる加工場になり得たと考え ます。また社内従業員はイントラネットのアプリケーショ ンを利用し、会社運営に必要なデーター(生産、受注、品
質、売上、在庫、仕掛、滞留)を容易に正確に抽出する事 が可能なった。それによって会社全体の状況が容易に正確 に社内ホームページのコンピューター画面によって必要な 情報を速やかに閲覧するができ、工場全体の加工工程状況 を瞬時に把握でき、生産管理者は生産体制をリアルタイム に最適な状態へ修正でき、さらに加工実績を蓄積する事に より正確な生産管理システムを構築することができた。今 後ますます国内の繊維業界は厳しくなると考えています。 その繊維業界の中の飯田繊工株式会社は中小企業ではあり ますが、染色整理業として生き残っていくための強い武器 になったと考えて扔ります。

\section{5. 今後の展開}

このシステムをさらに応用させ、染色整理業の中だけの 生産システムではなく、今後は飯田繊工株式会社のホーム ページを中心として、糸、編み、染色、縫製といった複雑 多岐にわたる川下 川中川上の生産状況を顧客に対して、 リアルタイムに公開する事によって、生産ラインに透明性 をもたせ、顧客にとって自社工場のように思って頂けるシ ステムを現在開発中であります。

\title{
『古文書・古典籍の料紙とその䇺 13 回和紙文化講演会
}

\author{
主 催：和紙文化研究会 後 援：文化財保存修復学会 日 時：平成 17 年 11 月 26 日(土) $10: 00 \sim 17: 15$ \\ 会 場：昭和女子大学グリーンホール 東急新玉川線三軒茶屋駅下車 南出口より徒歩 5 分 \\ 問合せ先：干110-8714 東京都台東区上野公園 12-8 東京藝術大学 大学院美術研究科 保存科学気付 第 13 回和紙文 \\ 化講演会事務局 稲葉 政満 東京藝大内 FAX: 03-5685-7780 特設携帯電話 090-6491-0791(この特設電 \\ 話は会期までの平日、13:00 18:00)
}

\section{2nd Annual Meeting of The Polymer Processing Society (略称 PPS-22) 国際高分子加工学会第 22 回年次大会}

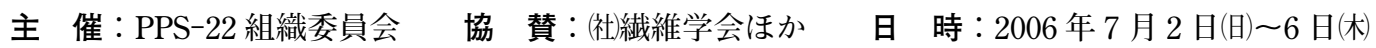

会＼cjkstart場：ホテルメトロポリタン山形(山形市) 内 容：講演、その他

問合せ先：PPS-22 事務局 担当：谷口、武田(山形大学工学部内)

E-mail : pps-22@yz.yamagata-u.ac.jp http ://www.PPS-22.com/ TEL: 0238-26-3056 FAX:0238-26-3411

\section{第 15 回アコースティック・エミッション＼cjkstart総合コンファレンス}

\section{主 催：(社)日本非破壊検査協会＼cjkstart協 賛：(社)繊維学会ほ力，日 時：平成 17 年 12 月 1 日(木) 2 日(金)}

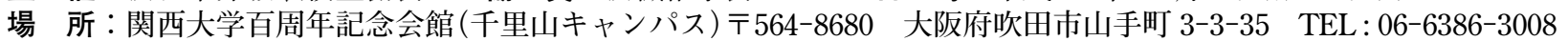
問合せ先：(社)日本非破壊検査協会 学術課 中村 TEL:03-5821-5105 FAX: 03-3863-6524

E-mail : nakamura@jsndi.or.jp http : //wwwsoc.nii.ac.jp/jsndi/

\section{第 52 回界面科学部会秋季セミナー 一化粧品、医薬品、農薬、食品製剤の最前線 一}

\section{主 催：日本油化学会 界面科学部会 協 賛: (社)繊維学会ほか 日 時：平成 17 年 11 月 1 日(月) 2 日(火)}

場＼cjkstart所：ホテル箱根アカデミー(神奈川県足柄下郡箱根町湖尻 160 TEL : 0460-4-7811)

問合せ先：横浜国立大学大学院 環境情報研究院 國枝研究室 荒牧 TEL\&FAX: 045-339-4300

E-mail : aramakik@ynu.ac.jp 